\title{
Soil Carbon Pools in California's Annual Grassland Ecosystems
}

\author{
Whendee L. Silver, ${ }^{1}$ Rebecca Ryals, ${ }^{2}$ and Valerie Eviner ${ }^{3}$
}

Authors are ${ }^{1}$ Professor and ${ }^{2}$ graduate student, Ecosystem Sciences Division, Department of Environmental Science, Policy, and Management, 137 Mulford Hall No. 3114, University of California, Berkeley, CA 94720, USA; and ${ }^{3}$ Assistant Professor, Department of Plant Sciences, University of CaliforniaDavis, 1210 PES, Mail Stop 1, One Shields Ave, Davis, CA 95616, USA.

\begin{abstract}
Rangeland ecosystems cover approximately one-third of the land area in the United States and half of the land area of California. This large land area, coupled with the propensity of grasses to allocate a considerable proportion of their photosynthate belowground, leads to high soil carbon (C) sequestration potential. Annual grasslands typical of the Mediterranean climates of the western United States differ in their life history strategies from the well-studied perennial grasslands of other regions and thus may also differ in their soil C pools and fluxes. In this study we use the literature to explore patterns in soil C storage in annual grass-dominated rangelands in California. We show that soil C is highly predictable with depth. Cumulative soil C content increased to 2-3-m depth in rangelands with a woody component and to at least $1-\mathrm{m}$ depth in open rangelands. Soil C within a given depth varied widely, with C content in the top 1-m depth spanning almost $200 \mathrm{Mg}$ $\mathrm{C} \cdot \mathrm{ha}^{-1}$ across sites. Soil C pools were not correlated with temperature or precipitation at a regional scale. The presence of woody plants increased C by an average of $40 \mathrm{Mg} \cdot \mathrm{ha}^{-1}$ in the top meter of soil. Grazed annual grasslands had similar soil C content as ungrazed grassland at all depths examined, although few details on grazing management were available. Soil C pools were weakly positively correlated with clay content and peaked at intermediated levels of aboveground net primary production. Our results suggest that annual grasslands have similar soil C storage capacity as temperate perennial grasslands and offer an important resource for mitigation of greenhouse gas emissions and climate change.
\end{abstract}

\section{Resumen}

Los ecosistemas de pastizales naturales cubren aproximadamente un tercio del área territorial de los EE. UU., y la mitad del área de California. Esta gran superficie, sumada a la propensión de los pastos a asignar una proporción considerable de sus fotosintatos a estructuras radiculares resulta en un alto potencial de secuestro de carbono (C). Los pastizales de especies anuales típicos de los climas Mediterráneos del oeste de los EE.UU. presentan estrategias de historias de vida diferentes de los pastizales perennes de otras regiones que han sido bien estudiados, y por lo tanto podrían también presentar diferencias en los flujos y reservas de carbono del suelo. En este estudio nos basamos en la literatura para explorar los patrones de almacenamiento de carbono en el suelo en pastizales dominados por especies anuales en California. Demostramos que el C en el suelo es altamente predecible a partir de la profundidad del suelo. El contenido acumulado de C en el suelo aumentó hasta los 2-3 m de profundidad en pastizales con un componente leñoso y hasta por lo menos $1 \mathrm{~m}$ de profundidad en pastizales abiertos. El contenido de $\mathrm{C}$ del suelo a una determinada profundidad varió ampliamente, con el C del primer metro de profundidad oscilando en casi $200 \mathrm{Mg} \mathrm{C} \cdot \mathrm{ha}^{-1}$ a lo largo de los sitios muestreados. Las reservas de $\mathrm{C}$ del suelo no correlacionaron con temperatura o precipitación a escala regional. La presencia de plantas leñosas incrementó el C en el primer metro de profundidad del suelo en $40 \mathrm{Mg} \cdot \mathrm{ha}^{-1}$ en promedio. Los pastizales anuales pastoreados tuvieron contenidos de C similares a los pastizales no pastoreados a todas las profundidades del suelo examinadas, aunque se encontraron pocos detalles sobre el manejo del pastoreo. Las reservas de $\mathrm{C}$ del suelo presentaron una correlación positiva débil con el contenido de arcillas, y fueron máximas en sitios con niveles intermedios de productividad primaria aérea neta. Nuestros resultados sugieren que los pastizales anuales presentan capacidades de almacenamiento de $\mathrm{C}$ similares a las de los pastizales de especies perennes de climas templados y ofrecen un recurso importante en la mitigación de la emisión de gases de invernadero y cambio climático.

Key Words: annual grassland, climate change, Mediterranean climate, oak woodland, soil carbon sequestration

This research was supported by a grant from the Environmental Defense Fund to W.L.S. Additional support came from the Kearney Foundation for Soil Science, the Rathmann Family Foundation, the Marin Community Foundation, and the California Agricultural Experiment Station (7673-MS to W.L.S.).

This publication was made possible through support provided to the Global Livestock Collaborative Research Support Program by the Office of Agriculture, Bureau for Economic Growth, Agriculture and Trade, United States Agency for International Development under terms of Grant No. PCE-G-00-98-00036-00. The opinions expressed herein are those of the author(s) and do not necessarily reflect the views of the USAID.

Correspondence: Whendee L. Silver, Ecosystem Sciences Division, Dept of Environmental Science, Policy, and Management, 137 Mulford Hall No. 3114, University of California, Berkeley, CA 94720, USA. Email: wsilver@berkeley.edu

Manuscript received 20 July 2009; manuscript accepted 8 November 2009.

\section{INTRODUCTION}

Soil carbon $(\mathrm{C})$ sequestration has been proposed as a means to lower greenhouse gas concentrations and help offset emissions (Intergovernmental Panel on Climate Change [IPCC] 2007). C sequestration in soils is accomplished by increasing the amount and/or mean residence time of $\mathrm{C}$ stored belowground. Several approaches have been proposed for increasing rates of soil C sequestration, including reforestation and afforestation of cropland and rangeland (Post and Kwon 2000), use of conservation tillage or no-till agriculture (Six et al. 2000; Del Grasso et al. 2009), improved grazing practices (Conant et al. 
2001), and organic amendments such as biochar (Lehmann 2007) and compost (Lal 2004; Smith 2004).

Rangeland soils are widely recognized for their potential to sequester C (Lal et al. 1995; Follett et al. 2001; Soussana et al. 2004; Smith et al. 2008), due in part to their extensive land area. Rangeland covers approximately $31 \%$ of the land area in the United States and an estimated $40-70 \%$ globally (Branson et al. 1981; Havstad et al. 2009). Furthermore, the relatively high ratio of evapotranspiration to precipitation in the grassland biome drives considerable belowground allocation by rangeland plants (Jackson et al. 1996). This high root biomass contributes to soil C pools directly through organic matter inputs and indirectly through increased soil aggregation and the formation of recalcitrant humic substances (Miller and Jastrow 1990; Balesdent and Balabane 1996).

Grazing management can affect soil $\mathrm{C}$ storage by altering above- and belowground plant $\mathrm{C}$ allocation (Holland et al. 1992; Johnson and Matchett 2001), net primary productivity (NPP; Frank and McNaughton 1993; Turner et al. 1993), and soil respiration (Kieft 1994; Bremer et al. 1998; Cao et al. 2004). Moderate grazing often increases aboveground NPP (ANPP; McNaughton 1985; Loeser et al. 2004), and in perennial grasslands ANPP is frequently positively correlated with soil C pools when controlling for precipitation (Parton et al. 1994).

Despite the well-recognized potential for rangelands to store $\mathrm{C}$, there have been few regional surveys of soil $\mathrm{C}$ pools in rangeland ecosystems (Bronson et al. 2004; Derner and Schuman 2007; Smith et al. 2008). Regional-scale soil C analyses that include information on patterns in climate, soil type, cover type, or management allow us to explore the relative sensitivity of soil $\mathrm{C}$ pools to the environment and to management practices. This information can then be used to identify promising approaches and technologies for $\mathrm{C}$ sequestration. Most of our understanding of $\mathrm{C}$ sequestration potential in US rangelands is from the Great Plains (Follett et al. 2001; Schuman et al. 2002; Derner and Schuman 2007). Although these systems occur along a gradient of mean annual precipitation and temperature, they are restricted to temperate climatic conditions that differ greatly from the Mediterranean climates of the western United States. These differences in climate may lead to significant differences in the temporal and spatial patterns in C storage and loss.

Rangelands cover approximately $50 \%$ of the state of California, a land area of approximately 24 million ha (Brown et al. 2004). Broadly defined, these ecosystems are characterized as grasslands, scrub, and woodlands (californiarangeland. ucdavis.edu), but the primary source of forage is from areas dominated by annual grasses and forbs, open oak woodlands, and occasional patches of both native and non-native perennial grasses, particularly near the coast (George et al. 2001; Jackson and Bartolome 2002). The climate varies throughout the state (Holland and Kiel 1995), with increasing precipitation from south to north, and from inland to coastal environments.

California rangelands differ in several ways from the perennial temperate grasslands of the Midwestern United States. California's climate is characterized by cool wet winters and warm dry summers. These grasslands are dominated by annual grasses and forbs, which germinate in the mid- to late fall, grow slowly throughout the winter months, and increase growth rates in the spring. They flower and die in late spring to early summer, leaving the soil surface covered in a thick layer of surface litter until rains commence again in the fall (Heady et al. 1991). This life history strategy is likely to favor a lower root-shoot allocation and shallower rooting depth than perennial grasslands, as no active plant biomass occurs over the dry summer months (Heady et al. 1991). A low root-shoot ratio and shallow roots could lead to lower soil C storage relative to perennial grasslands.

In California's annual grassland, each season's peak aboveground biomass is equivalent to its ANPP. ANPP is partially influenced by temperature, precipitation, soils, and the amount of residual dry matter (RDM), the previous year's aboveground biomass remaining at the beginning of the growing season (Hedrick 1948; Heady 1956, 1965; George et al. 1985). Grazing management in annual grasslands is often based on this relationship between RDM and the ensuing year's productivity (George et al. 1985) and may feed back on soil C pools and fluxes. Aboveground NPP tends to peak at moderate to high levels of RDM (indicator of moderate to no grazing; Bartolome et al. 2007). In contrast, decreased RDM (indicator of increased grazing) leads to higher root:shoot ratios in these annual grasses (Betts 2003). Most temperate perennial grasses have been found to decrease root:shoot ratios in response to defoliation, highlighting that the different responses of annual vs. perennial grasses to grazing limit our ability to predict the impacts of grazing practices on these annual systems based on data from perennial grasslands (reviewed in Bartolome et al. 2007).

We have compiled data from peer-reviewed literature to estimate the quantity of $\mathrm{C}$ stored in rangeland soils in California and to explore the effects of climate, soil type, vegetation cover type, grazing, and ANPP. Our goals were to provide an estimate of current levels of soil C storage in California rangelands and to identify promising approaches for increased $\mathrm{C}$ sequestration in the future.

\section{METHODS}

We extracted data from peer-reviewed journal articles that reported sampling depth and soil organic C content, or sampling depth, soil C concentration, and bulk density from California rangelands (Table 1). Rangelands were defined broadly and included grasslands, oak savanna, oak woodland, coastal grassland complexes, and woody savannas. Only studies that included data on soil $\mathrm{C}$ pools with at least partial grass cover were included here $(n=48$ separate soil profiles, 216 data points). Using the same publications or others from the same sites we collected information on soil order, latitude, longitude, mean annual temperature, mean annual precipitation, ANPP during the study period (ANPP of grass component), clay concentration (\%), and grazing management (grazed, ungrazed). We also recorded the vegetation cover type (presence or absence of woody plants, herbaceous perennial plants, and nitrogen $[\mathrm{N}]$ fixers); however, insufficient data were available for meta-analyses of all variables except presence or absence of woody plants. Only profiles and depths reporting direct measurements (i.e., not modeled values) were used. 
Table 1. Studies reporting soil $\mathrm{C}$ content in California rangelands. ${ }^{1}$

\begin{tabular}{|c|c|c|c|c|c|}
\hline Study & $\begin{array}{c}\text { Profile } \\
\text { (no.) }\end{array}$ & $\begin{array}{l}\text { Mean annual temperature } \\
\left({ }^{\circ} \mathrm{C}\right)\end{array}$ & $\begin{array}{l}\text { Mean annual precipitation } \\
(\mathrm{mm})\end{array}$ & $\begin{array}{l}\text { Latitude } \\
\left({ }^{\circ}\right)\end{array}$ & $\begin{array}{c}\text { Longitude } \\
\left({ }^{\circ}\right)\end{array}$ \\
\hline Dahlgren et al. (1997) & 4 & 15 & 730 & 39.2 & 121.2 \\
\hline Herman et al. (2003) & 3 & 15 & 730 & 39.2 & 121.2 \\
\hline Steenwerth et al. (2002) & 4 & 14.25 & 425 & NA & NA \\
\hline Fierer et al. (2005) & 6 & 22 & 500 & 34.4 & 120.0 \\
\hline Camping et al. (2002) & 3 & 15 & 730 & 39.2 & 121.7 \\
\hline Jackson et al. (1988) & 1 & 15 & 730 & 39.2 & 121.2 \\
\hline Chou et al. (2008) & 1 & 16 & 750 & 39.2 & 121.2 \\
\hline Trumbore et al. (1996) & 1 & 17.8 & 310 & 36.7 & 119.3 \\
\hline Carbone et al. (2008) & 1 & 24 & 150 & 37.4 & 118.4 \\
\hline \multicolumn{6}{|c|}{ Sanderman et al. (2008); Sanderman and } \\
\hline Gessler et al. (2000) & 9 & 22 & 380 & 34.4 & 120.2 \\
\hline Masiello et al. (2004) & 7 & 12 & $>1000$ & NA & NA \\
\hline
\end{tabular}

${ }^{1} \mathrm{NA}$ indicates data not available.

Sampling depths ranged from $2 \mathrm{~cm}$ to $365 \mathrm{~cm}$ and varied widely within and among studies. Soil $\mathrm{C}$ content varies as a function of the depth to which soil is sampled, and for this reason some standardization is required to compare among sites where different soil depths are sampled. This approach is valid for regional scale analyses (Jobbagy and Jackson 2000; Silver et al. 2000, 2002) but is less appropriate for site-specific data. We used a simple modeling procedure to standardize depths across the 48 profiles to facilitate comparisons among studies (Jobbagy and Jackson 2000; Silver et al. 2000, 2002). Soil C pools were summed by depth to estimate cumulative soil $\mathrm{C}$ pools for every possible depth within a profile (e.g., for a profile that sampled $0-2-\mathrm{cm}, 2-10-\mathrm{cm}$, and $10-30-\mathrm{cm}$ depth we calculated C pools for $0-2-\mathrm{cm}, 0-10-\mathrm{cm}$, and $0-30-\mathrm{cm}$ depths). We then used the entire dataset to plot cumulative soil C pools with depth; we fit one curve to all the data, estimating the goodness of fit using regression analyses. In our first analysis we used all the data available, which allowed us to determine if patterns existed and identify any obvious statistical outliers, using analysis of variance (Systat 11; Systat Software Inc., Chicago, IL). Through this procedure, we identified eight profiles derived from a single study in northwestern California and one profile from central California as outliers. Outliers were removed and treated separately in all subsequent analyses and are discussed below (see Results). The remaining 39 profiles are hereafter referred to as primary profiles.

Using the primary profiles we again plotted cumulative soil C with depth and derived the following equation:

$$
y=-2.79 x^{2}+1725 x+13241
$$

where $y$ is the soil C pool at depth $x\left(r^{2}=0.90, n=145\right)$. We used Equation 1 to generate one modeled $\mathrm{C}$ value for each soil depth increment reported in the literature (e.g., $0-2 \mathrm{~cm}, 0$ $2.5 \mathrm{~cm}, 0-8 \mathrm{~cm}$, etc.; $n=80$ ). We then estimated soil $\mathrm{C}$ pools at target depths of $10 \mathrm{~cm}, 25 \mathrm{~cm}, 50 \mathrm{~cm}$, and $100 \mathrm{~cm}$ for each profile by multiplying the measured $\mathrm{C}$ content at the depth from each profile that was closest to the target depth by a conversion factor. The conversion factor was the ratio of modeled C at the target depth (Eq. 1: $y(x) 10 \mathrm{~cm}, 25 \mathrm{~cm}$, $50 \mathrm{~cm}$, or $100 \mathrm{~cm}$ ) to the $\mathrm{C}$ modeled at the nearest depth reported in the literature (Eq. 1 using the measured depth for $x$ that was closest to the target depth). For example, cumulative $\mathrm{C}$ for a depth of $50 \mathrm{~cm}$ in a profile where the closest reported depth is $40 \mathrm{~cm}$ was calculated as: measured C at $40 \mathrm{~cm} \cdot y(50) /$ $y(40)$.

We used data modeled to the four depths to determine the effects of climate, grazing, and woody plants on soil $\mathrm{C}$ pools at the four depths. We also explored relationships of soil C with ANPP. Data were log transformed when appropriate to meet the assumptions of analysis of variance. Statistical analyses were performed using Systat 11. Statistical significance was determined at the $95 \%$ level unless otherwise noted. Values in the text are means $\pm 1 \mathrm{SE}$.

\section{RESULTS}

Cumulative soil C pools followed a predictable pattern with depth when using the primary soil profiles $\left(r^{2}=0.90, n=39\right.$ profiles; Fig. 1A). The pattern was surprisingly linear for the top $2 \mathrm{~m}$ and appeared to saturate only near $3 \mathrm{~m}$ in rangelands with a woody component. Rangelands without a woody component were sampled only to $1-\mathrm{m}$ depth. Cumulative soil C pools were greatest in the top $20 \mathrm{~cm}$ but were relatively linear over most of this range. The outliers followed similar patterns but were generally offset from the primary profiles (Fig. 1B). One profile, reported in Gessler et al. (2000), had higher-than-average soil $\mathrm{C}$ content at each of eight depth increments (Fig. 1A). This profile was located in a small but deep valley/canyon at the confluence of two drainages. Surface soils had accumulated via runoff from the surrounding area, 

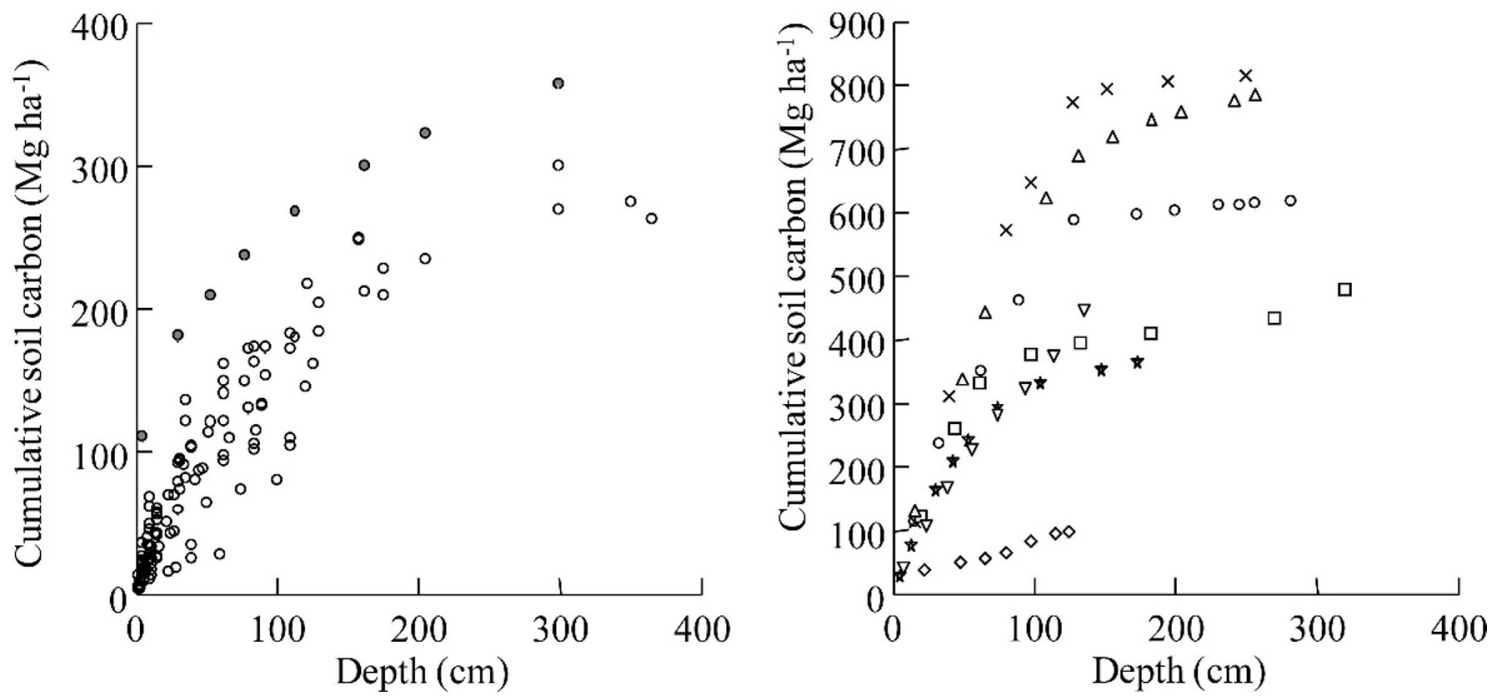

Figure 1. Cumulative carbon pools by depth in California rangeland soils. A, Primary profiles $(n=40) ; y=-2.79 x^{2}+1725 x+13241 ; r^{2}=0.90$; filled dots are from Gessler et al. (2000). B, Data from Masiello et al. (2004).

leading to a very C-rich profile (O. Chadwick, personal communication, May 2009). A set of profiles from a study conducted by Masiello et al. (2004) on the northern California coast did not follow the pattern of the primary profiles (Fig. 1B). The soil C measured in this study exceeded that of the other studies, with the exception of one profile in relatively recent soils $(\sim 3.9$ thousand yr old). The high soil $\mathrm{C}$ content of these soils is intriguing and may result from previous land cover in forest, due to the presence of deep coarse roots found in some pits (O. Chadwick, personal communication, May 2009). Cumulative soil $\mathrm{C}$ pools reached an asymptote between 1-m depth and 2-m depth at this site.

There was a wide range in soil C pools at all modeled depths, and the range increased as more of the soil profile was considered (Table 2; Fig. 2). Soil C pools from the primary profiles ranged from $28 \mathrm{Mg} \mathrm{C} \cdot \mathrm{ha}^{-1}$ to $137 \mathrm{Mg} \mathrm{C} \cdot \mathrm{ha}^{-1}$ in the 0-50-cm depth and spanned $173 \mathrm{Mg} \mathrm{C} \cdot \mathrm{ha}^{-1}$ when considering the top meter of soil. There was an average of $90 \pm 5 \mathrm{Mg}$ $\mathrm{C} \cdot \mathrm{ha}^{-1}$ to $50-\mathrm{cm}$ depth and $140 \pm 7 \mathrm{Mg} \mathrm{C} \cdot \mathrm{ha}^{-1}$ to $1-\mathrm{m}$ depth. The potential controlling factors most likely to mediate this variability that were available from the literature included soil type, clay content, climate, ANPP, and grazing history. Alfisols $(n=18)$ and Mollisols $(n=14)$ were the two dominant soil orders and had similar soil C content (data not shown). Although soil type did not significantly contribute to variation in soil C, soil C pools were positively correlated with clay content below 10-cm depth (Fig. 3). Mean annual temperature across sampling points ranged from $14^{\circ} \mathrm{C}$ to $24^{\circ} \mathrm{C}$, and mean annual precipitation ranged between $150 \mathrm{~mm} \cdot \mathrm{yr}^{-1}$ and $1300 \mathrm{~mm} \cdot \mathrm{yr}^{-1}$. There were no statistically significant trends in soil C pools with temperature or precipitation. Aboveground NPP was available for 19 profiles and varied from $129 \mathrm{~kg} \cdot \mathrm{ha}^{-1} \cdot \mathrm{yr}^{-1}$ to $>8000 \mathrm{~kg} \cdot \mathrm{ha}^{-1} \cdot \mathrm{yr}^{-1}$. Rates of ANPP were significantly greater above $500-\mathrm{mm}$ mean annual precipitation and $20^{\circ} \mathrm{C}$ mean annual temperature, but much of the variation in ANPP was not explained by climate variables. Soil
C content peaked at intermediate levels of ANPP $(y=$ $-14.8 x^{2}+201.7 x-55.6, \quad r^{2}=0.44, \quad P<0.01, \quad F=6.3216$; 50 -cm depth).

The presence of a woody component in rangelands significantly increased soil C pools for $0-25-\mathrm{cm}, 0-50-\mathrm{cm}$, and $0-100-\mathrm{cm}$ depths (Table 2). In the top meter of soil, woody plants increased soil $\mathrm{C}$ pools by approximately $40 \mathrm{Mg} \mathrm{C} \cdot \mathrm{ha}^{-1}(116 \pm 9$ vs. $155 \pm 9 \mathrm{Mg} \mathrm{C} \cdot \mathrm{ha}^{-1}$ in nonwoody vs. woody rangelands). Grazed sites had slightly more soil $\mathrm{C}$ at all modeled depths than ungrazed ones, but the differences were small and statistically insignificant at this level of resolution (Table 2). It is important to note that grazing management likely varied among the studies with regard to history, duration, and intensity.

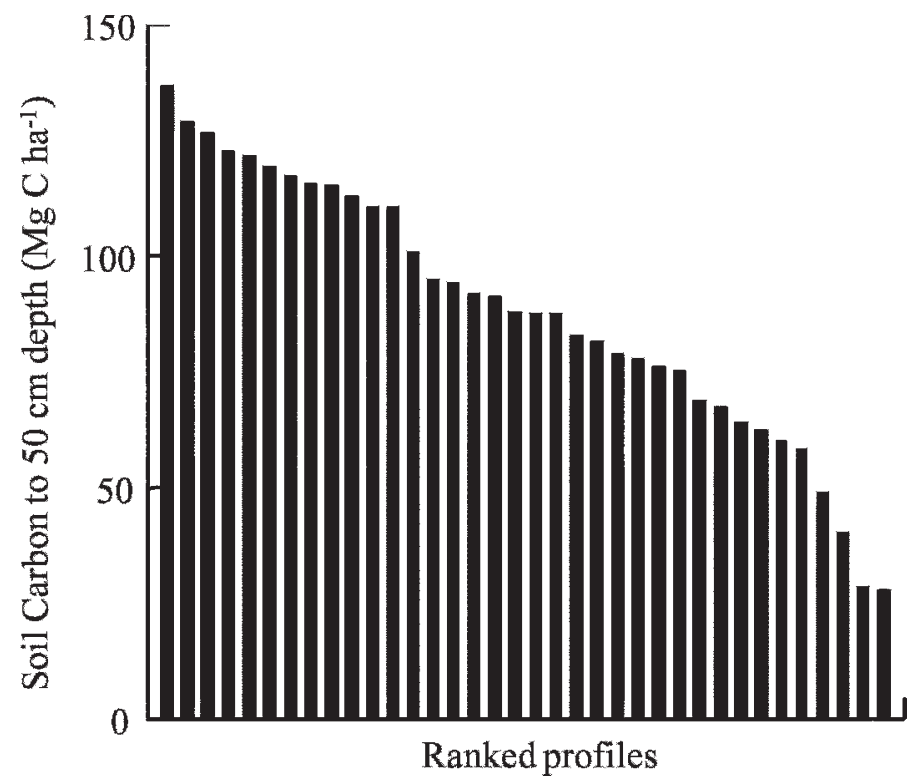

Figure 2. Modeled soil carbon to $50-\mathrm{cm}$ depth (ranked from highest to lowest) for the primary profiles. 


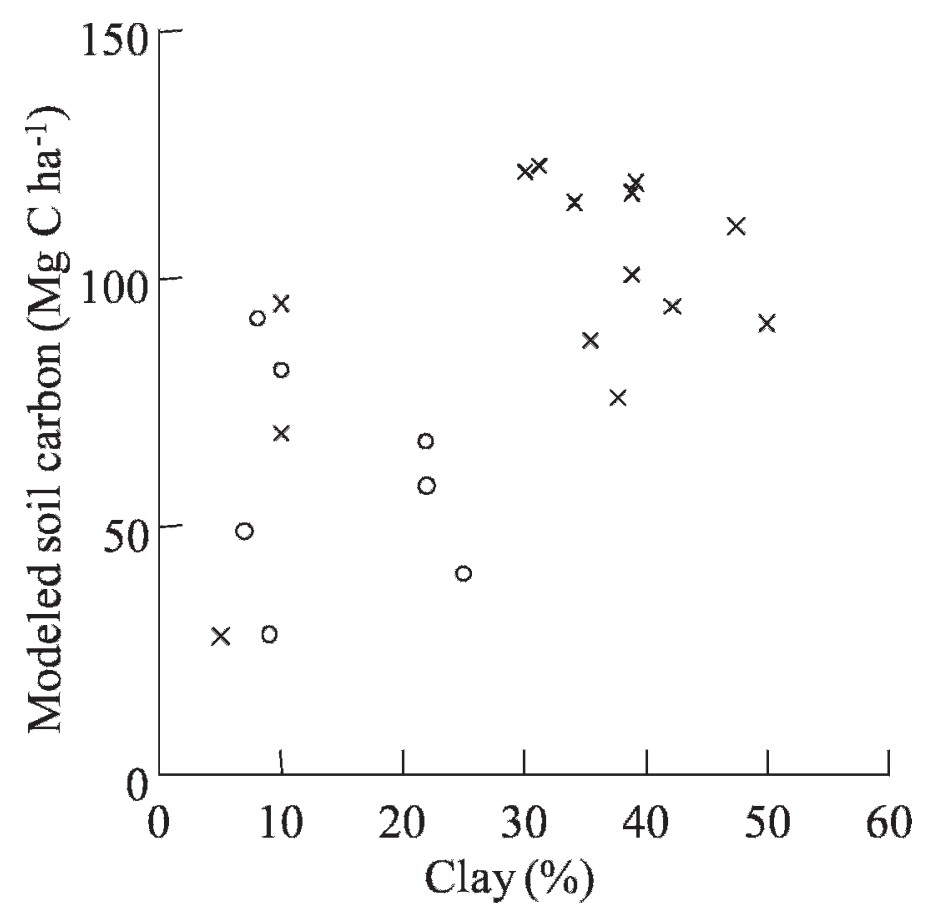

Figure 3. Modeled soil carbon content $\left(\mathrm{Mg} \mathrm{C} \cdot \mathrm{ha}^{-1}\right)$ plotted against soil clay content $(\%) ; r^{2}=0.27, P<0.01 ; X=$ rangeland with woody component; $0=$ rangeland without woody component.

Published studies on soil C pools were concentrated at relatively few research sites throughout the state (Fig. 4). Eleven of the primary profiles were at the Sierra Foothills Research and Extension Center, Browns Valley, Yuba County (lat $39^{\circ} 15^{\prime} \mathrm{N}$, long $121^{\circ} 17^{\prime} \mathrm{W}$ ). Thirteen profiles were located at the University of California Sedgewick Natural Reserve in the Santa Ynez River Basin, Santa Barbara County (lat $34^{\circ} 42^{\prime} \mathrm{N}$, long $\left.120^{\circ} 03^{\prime} \mathrm{W}\right)$. Within site variability was relatively high at sites with multiple profiles; this is not surprising given that sampling locations were often selected to compare contrasting environmental conditions and treatments. Very few studies reporting soil $\mathrm{C}$ have been conducted in the more arid southern and southeastern portions of the state.

\section{DISCUSSION}

\section{Regional Patterns in Soil Carbon Pools}

Few regional surveys have been performed of soil $\mathrm{C}$ pools in rangeland ecosystems. Soil C pools in California rangelands were slightly larger than the average values for grasslands and

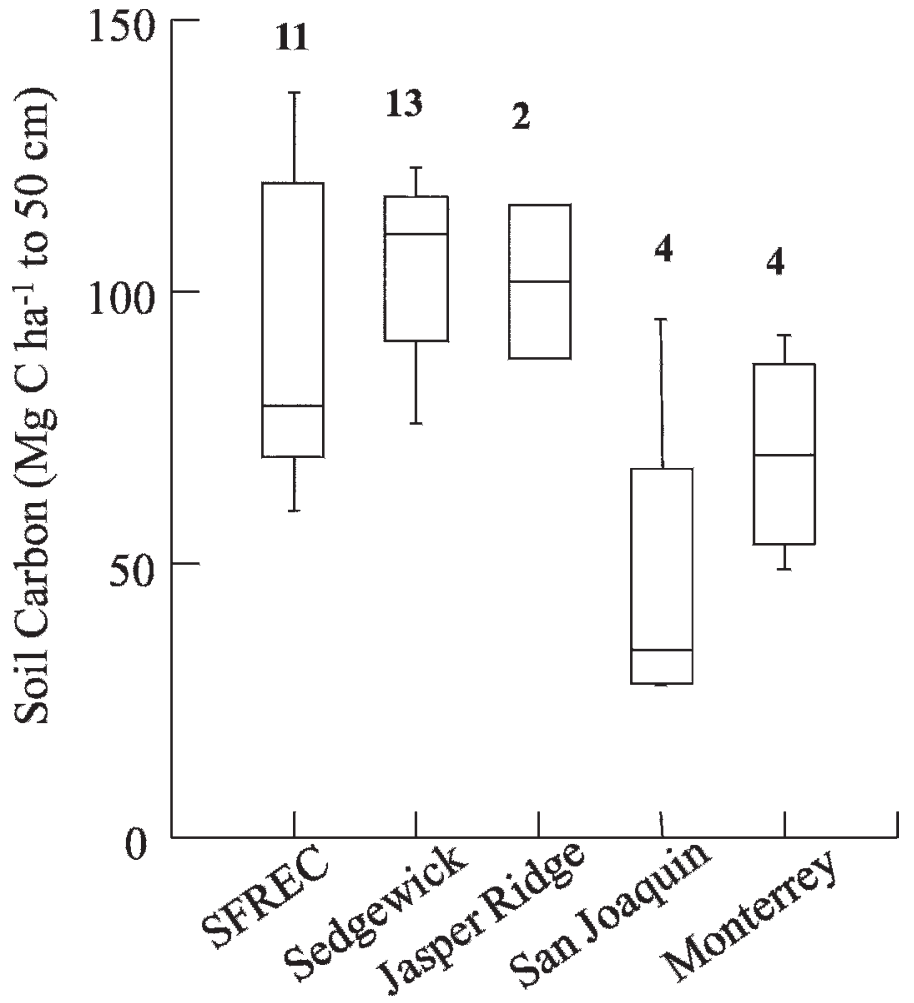

Figure 4. Box and whisker plots showing range of soil carbon data from the five dominant study sites. Numbers above each box indicate the number of profiles used from that site.

pastures for the conterminous United States for the top $100 \mathrm{~cm}$ (Guo et al. 2006). Soil C pools in this study averaged $90 \mathrm{Mg}$ $\mathrm{C} \cdot \mathrm{ha}^{-1}$ in the top $50 \mathrm{~cm}$. This is lower than values reported for perennial grasslands in Texas, which stored approximately $100 \mathrm{Mg} \mathrm{C} \cdot \mathrm{ha}^{-1}$ in the top $40 \mathrm{~cm}$ of soils (Potter and Derner 2006). Burke et al. (1989) estimated soil C pools to $20-\mathrm{cm}$ depth from 500 rangeland sites in the Great Plains using soil survey data. They reported soil $\mathrm{C}$ pools that ranged from less than $10 \mathrm{Mg} \mathrm{C} \cdot \mathrm{ha}^{-1}$ to almost $90 \mathrm{Mg} \mathrm{C} \cdot \mathrm{ha}^{-1}$ and were correlated with broad climate differences across the region. They found that cool, moist climates and clay soils led to the largest soil C pools. California's soil C pools in the top $20 \mathrm{~cm}$ averaged $50 \pm 4 \mathrm{MgC} \cdot \mathrm{ha}^{-1}$. These fall within the range found in the Great Plains, and when compared to sites in the Great Plains with similar averaged climate values (mean annual temperature was $19 \pm 0.3^{\circ} \mathrm{C}$ and mean annual precipitation was $517 \pm 16 \mathrm{~mm}$ ), soil $\mathrm{C}$ pools in California were greater than

Table 2. Patterns in soil carbon pools $\left(\mathrm{Mg} \mathrm{C} \cdot \mathrm{ha}^{-1}\right)$ with depth in California rangeland soils. Data are modeled using a simple quadratic equation with soil carbon content and depth (see text). ${ }^{1}$

\begin{tabular}{|c|c|c|c|c|c|c|}
\hline \multirow{2}{*}{$\begin{array}{c}\text { Depth } \\
(\mathrm{cm})\end{array}$} & \multicolumn{2}{|c|}{ Overall } & \multirow{2}{*}{$\begin{array}{c}\text { Woody } \\
(\text { mean } \pm \text { SE) }\end{array}$} & \multirow{2}{*}{$\begin{array}{c}\text { Nonwoody } \\
\text { (mean } \pm \mathrm{SE})\end{array}$} & \multirow{2}{*}{$\begin{array}{c}\text { Ungrazed } \\
(\text { mean } \pm \text { SE) }\end{array}$} & \multirow{2}{*}{$\begin{array}{c}\text { Grazed } \\
(\text { mean } \pm \mathrm{SE})\end{array}$} \\
\hline & Mean \pm SE & $\operatorname{Min} / \max$ & & & & \\
\hline $0-10$ & $33 \pm 4$ & $11 / 152$ & $36 \pm 7$ & $27 \pm 3$ & $32 \pm 5$ & $34 \pm 4$ \\
\hline $0-25$ & $58 \pm 4$ & $16 / 158$ & $66 \pm 7$ & $44 \pm 4^{*}$ & $52 \pm 7$ & $57 \pm 6$ \\
\hline $0-50$ & $90 \pm 5$ & $28 / 200$ & $101 \pm 7$ & $71 \pm 6^{*}$ & $80 \pm 9$ & $89 \pm 8$ \\
\hline $0-100$ & $140 \pm 7$ & $47 / 246$ & $155 \pm 9$ & $116 \pm 9^{*}$ & $127 \pm 12$ & $141 \pm 13$ \\
\hline
\end{tabular}

${ }^{1}$ Asterisks signify statistically significant differences among treatments (woody vs. nonwoody and ungrazed vs. grazed). Sample size (per depth) was 40 for overall data, 25 for woody rangelands, 15 for nonwoody sites, 9 for ungrazed, and 11 for grazed rangelands. 
in Central Plains rangelands $\left(\sim 20 \mathrm{Mg} \mathrm{C} \cdot \mathrm{ha}^{-1}\right)$ for the same depth. Unlike the Great Plains, most rangelands in California rarely experience prolonged low temperatures, and most of the annual precipitation in California falls as rain during the growing season. This likely maximizes the use of precipitation by grasses, while during the warm summer months soil organic matter decomposition is likely inhibited due to lack of adequate soil moisture. We did not see a relationship between precipitation and soil $\mathrm{C}$ in California rangeland soils. Soil $\mathrm{C}$ pools increased with clay content in this study. Finely textured soils have greater reactive surface area and tend to store more $\mathrm{C}$ than more coarsely textured soils (Schimel et al. 1994). Soil C pools were greatest at intermediate levels of ANPP. This may result from patterns in plant allocation, with greater belowground allocation contributing proportionally more to soil C pools (Balesdent and Balabane 1996; Christian and Wilson 1999; Puget and Drinkwater 2001).

Our analyses show that the cumulative C content of rangeland soils in California was strongly predictable with depth. The strong relationship of soil $\mathrm{C}$ pools with depth suggests that although local properties may contribute to variability in the baseline amount of $\mathrm{C}$ in these soils, inherent properties of rangelands control patterns of $\mathrm{C}$ accumulation and storage over the soil profile. Although our dataset includes multiple profiles from a subset of sites, the studies used in this analysis spanned multiple bioclimatic regions (semiarid to mesic), soil types (alfisols and mollisols), cover types (annual grasslands and oak woodlands), and management (ungrazed and a range of grazing intensities). The trend in soil $\mathrm{C}$ accumulation with depth was nearly linear over $2 \mathrm{~m}$ in rangelands with a woody component and over $1 \mathrm{~m}$ in open rangelands. Most of the rangelands in this study were dominated by annual grasses, which are generally thought to have shallow rooting depth relative to perennial grasses (Savelle 1977). Although $C$ was concentrated in the surface $20-40 \mathrm{~cm}$, these data demonstrate significant $\mathrm{C}$ storage potential in deeper soil horizons in grasslands dominated by annual plants. Woody plants added significant soil C below $1 \mathrm{~m}$, but annual grasslands without a woody component still showed increasing $\mathrm{C}$ content to $1-\mathrm{m}$ depth. This may be due to the presence of residual soil C from the historical presence of woody plants or even perennial grasses, although annual grasses have dominated this region for more than $100 \mathrm{yr}$. Alternatively it is possible that some grass species may be able to access deeper soils with roots. Some annual grassland plants allocate over $30 \%$ of their root mass below 30-cm depth (Gordon and Rice 1992). Soil C may be also translocated down in the soil profile by earthworms or water (Shuster et al. 2001; Mariani et al. 2007). Sequestering C deep in the soil profile could partially offset increasing atmospheric $\mathrm{CO}_{2}$ concentrations. Soil $\mathrm{C}$ stored in subsurface horizons is likely to be less biologically active due to lower resource availability for decomposers, lower redox potential, potentially higher concentrations of more recalcitrant $\mathrm{C}$ compounds that resist decay (Silver et al. 1999; Chabbi et al. 2009), and lower probability of soil physical disturbance.

Rangelands with a woody component had significantly more soil $\mathrm{C}$ below $10-\mathrm{cm}$ depth than open grasslands. In the top $100 \mathrm{~cm}$ this amounted to almost $40 \mathrm{Mg} \mathrm{C} \cdot \mathrm{ha}^{-1}$. Our analysis could not account for the species composition, density, biomass, or productivity of woody plants in the rangelands surveyed, nor historical patterns of woody plant distribution and biomass, all of which can impact soil C pools. Regardless, sites that contained woody plants at the time of sampling consistently had high soil C pools, even when controlling for temperature and precipitation. Oak woodlands and wooded savanna make up a significant proportion of the rangelands in California (Griffen 1977). These ecosystems are characterized by tree islands in a grassland matrix. Oak understories tend to have higher soil $\mathrm{C}$ and nutrient pools and lower bulk densities than the surrounding grasslands (Dahlgren et al. 1997). Oaks have greater rooting depth than grasses, providing an important contribution to deep soil C. These ecosystems may also be better at retaining $\mathrm{C}$ over time due to more complete use of seasonally available water (Ma et al. 2007). Rangeland management, oak removal to increase forage production, increasing urban development, vineyard expansion, and Sudden Oak Death have led to a decline in oaks in California rangelands that may negatively impact $\mathrm{C}$ storage and nutrient cycling in these soils (Dahlgren et al. 1997; Giusti et al. 2004; Gaman and Firman 2006; but see Kroodsma and Field 2006).

Oaks are not the only woody plants that occur in California rangelands. Coastal rangelands have been experiencing an invasion of Baccharis pilularis over the last $50 \mathrm{yr}$ (McBride and Heady 1968; Hobbs and Mooney 1986; Stromberg et al. 2001; Zavaleta and Kettley 2006). Baccharis invasion increased soil C pools in a semiarid rangeland, but decreased total ANPP by $67 \%$ over 25 yr (Zavaletta and Kettley 2006). Woody encroachment is increasing worldwide (Van Auken et al. 2000; Schroter et al. 2005; Hobbs et al. 2006) due to grazing (Schlesinger et al. 1990) and fire management (Bond and Keeley 2005), as well as anthropogenic N deposition (Kochy and Wilson 2001) and elevated atmospheric $\mathrm{CO}_{2}$ concentrations (Bond and Midgley 2000; Polley et al. 2003). Although woody plants can significantly increase soil $\mathrm{C}$ pools, they also present some ecological and economic costs in rangelands (Jackson et al. 2005). Deep-rooting trees can alter the hydrology of grassland ecosystems, increasing salinity and altering nutrient dynamics (Jobbagy and Jackson 2004; McCully et al. 2004; Jackson et al. 2005). Woody plants can decrease forage for livestock, negatively impacting yields. Woody invasion does not always increase soil C pools in grasslands. Jackson et al. (2000) found that woody invasion decreased soil C content in perennial grasslands receiving $\geq 660 \mathrm{~mm}$ rainfall per year, amounts typical of many Mediterranean climates.

Grazing can impact soil C pools by affecting C inputs via NPP, turnover rates, root to shoot allocation, and $\mathrm{C}$ exports via decomposition, erosion, and hydrologic losses. In a review of largely perennial grasslands, Conant et al. (2001) found that improved grazing practices such as moderate stocking rates significantly increased rates of soil $\mathrm{C}$ sequestration, averaging $0.35 \mathrm{Mg} \mathrm{C} \cdot \mathrm{ha}^{-1} \cdot \mathrm{yr}^{-1}$. They found that rates of soil $\mathrm{C}$ sequestration were greatest in warm dry regions with high potential evapotranspiration and with a long prior history of grazing, similar to many rangelands in California. In our analysis grazing appeared to have no significant impact on soil $\mathrm{C}$ pools in California rangelands. This is not necessarily surprising at the level to which this could be evaluated in this dataset. The timing, frequency, and intensity 
of grazing, data that were not available for the current analysis, strongly influence a system's response to grazing. For example, the timing of grazing has a strong impact on vegetation composition, particularly the prevalence of laterseason, deeper-rooted species (reviewed in Huntsinger et al. 2007; Jackson and Bartolome 2007). The impacts of RDM, an indicator of grazing intensity, on ANPP can vary by site and year (Bartolome et al. 2007), and its impacts on a given site may be masked by analyzing across broadly different conditions. Consideration of such context-dependent interactions is critical for effective ecosystem management (Eviner and Hawkes 2008).

\section{Distribution of Available Data on Soil Carbon Pools}

Our review of the literature highlights the range of bioclimatic zones that have been well studied in California and those that are poorly studied. Thirty-nine of the 48 profiles used in our analysis were located at just five sites throughout the state. Obvious gaps in data include annual grasslands in arid regions as well as montane rangelands. More data from these environments will help facilitate modeling at a regional scale. In this study we have focused on soil organic $\mathrm{C}$, but significant inorganic $\mathrm{C}$ can occur in some arid and semiarid environments (Eshel et al. 2007) and deserves more attention.

\section{MANAGEMENT IMPLICATIONS}

Soil C sequestration has been proposed as a means to help offset greenhouse gas emissions and reduce the atmospheric burden of $\mathrm{CO}_{2}$ (IPCC 2007). Understanding patterns in soil C storage is a first step to exploring soil $\mathrm{C}$ sequestration potential. The wide range in soil $\mathrm{C}$ pools in California's rangelands across similar soil types and climate suggests considerable potential to increase soil $\mathrm{C}$ storage in these ecosystems through management. The presence of woody plants is likely to facilitate $\mathrm{C}$ storage at depth. However, increased woody plant biomass often comes at the expense of forage production, can result in soil salinization, and result in significant water loss at an ecosystem scale (Jobbagy and Jackson 2004; McCully et al. 2004; Jackson et al. 2005). Improved grazing practices, organic amendments, and irrigation have been proposed as mechanisms to increase $\mathrm{C}$ storage in rangeland soils. Soil $\mathrm{C}$ sequestration in rangelands is likely to be a relatively inexpensive approach to climate change mitigation, with many co-benefits in the form of higher plant production, increased soil water-holding capacity, and decreased soil erosion (Paustian et al. 1997).

\section{LITERATURE CITED}

Baisden, W. T., R. Amundson, D. L. Brenner, A. C. Cook, C. Kendall, and J. W. Harden. 2002a. A multiisotope $\mathrm{C}$ and $\mathrm{N}$ modeling analysis of soil organic matter turnover and transport as a function of soil depth in a California annual grassland soil chronosequence. Global Biogeochemical Cycles 16:1135.

Baisden, W. T., R. Amundson, A. C. Cook, and D. L. Brenner. 2002b. Turnover and storage of $\mathrm{C}$ and $\mathrm{N}$ in five density fractions from California annual grassland surface soils. Global Biogeochemical Cycles 16:1117.

Baisden, W. T., and R. L. Parfitt. 2007. Bomb C-14 enrichment indicates decadal C pool in deep soil? Biogeochemistry 85:59-68.
Balesdent, J., and M. Balabane. 1996. Major contribution of roots to soil carbon storage inferred from maize cultivated soils. Soil Biology and Biochemistry 28:1261-1263.

Bartolome, J. W., R. D. Jackson, A. D. K. Betts, J. M. Connor, G. A. Nader, and K. W. TATE. 2007. Effects of residual dry matter on net primary production and plant functional groups in Californian annual grasslands. Grass and Forage Science 62:445-452.

BetTs, K. 2003. Demonstrating carbon sequestration. Environmental Science \& Technology 37:354A-355A.

Bond, W. J., AND J. E. KeELEY. 2005. Fire as a global 'herbivore': the ecology and evolution of flammable ecosystems. Trends in Ecology and Evolution 20:387-394.

Bond, W. J., AND G. F. MIDGLEY. 2000. A proposed C02-controlled mechanism of woody plant invasion in grasslands and savannas. Global Change Biology 6:865-869.

Branson, F. A., G. G. Gifford, K. G. Renard, and R. F. Hadley. 1981. Rangeland hydrology. Dubuque, IA, USA: Kendall/Hunt Publishing Company. $84 \mathrm{p}$.

Bremer, D. J., J. M. Ham, C. E. Owensby, and A. K. Knapp. 1998. Responses of soil respiration to clipping and grazing in a tallgrass prairie. Journal of Environmental Quality 27:1539-1548.

Bronson, K. F., T. M. Zobeck, T. T. Chua, V. Acosta-Martinez, R. S. van Pelt, and J. D. Booker. 2004. Carbon and nitrogen pools of southern high plains cropland and grassland soils. Soil Science Society of America Journal 68:1695-1704.

Brown, S., A. Dushiu, T. Pearson, D. Shoch, J. Winsten, S. Sweet, and J. Kadyszewski. 2004. Carbon supply from changes in management of forest, range, and agricultural lands of California. Sacramento, CA, USA: Winrock International, for the California Energy Commission, PIER Energy-Related Environmental Research. 500-04-068F. 144 p.

Burke, I. C., C. M. Yonker, W. J. Parton, C. V. Cole, K. Flach, and D. S. Schimel. 1989. Texture, climate, and cultivation effects on organic matter content in US grassland soils. Soil Science Society of America Journal 53:800-805.

Camping, T. J., R. A. Dahlgren, K. W. Tate, and W. R. Horwath. 2002. Changes in soil quality due to grazing and oak tree removal in California blue oak woodlands. In: R. B. Standiford, D. McCreary, and K. L. Purcell (EDS.). Oaks in California's changing landscape. Berkeley, CA, USA: US Department of Agriculture, General Technical Report PSW-184. p. 75-85.

Cao, G. M., Y. H. TAng, W. H. Mo, Y. A. Wang, Y. N. LI, And X. Q. Zhao. 2004. Grazing intensity alters soil respiration in an alpine meadow on the Tibetan plateau. Soil Biology \& Biochemistry 36:237-243.

Carbone, M. S., G. C. Winston, and S. E. Trumbore. 2008. Soil respiration in perennial grass and shrub ecosystems: linking environmental controls with plant and microbial sources on seasonal and diel timescales. Journal of Geophysical Research 113:G02022.

Chabbi, A., I. Kogel-Knabner, and C. Rumpel. 2009. Stabilised carbon in subsoil horizons is located in spatially distinct parts of the soil profile. Soil Biology \& Biochemistry 41:256-261.

Chou, W. W., W. L. Silver, R. D. Jackson, A. W. Thompson, and B. Allen-Diaz. 2008. The sensitivity of annual grassland carbon cycling to the quantity and timing of rainfall. Global Change Biology 14:1382-1394.

Christian, J. M., and S. D. WiLson. 1999. Long-term ecosystem impacts of an introduced grass in the northern Great Plains. Ecology 80:2397-2407.

Conant, R. T., K. Paustian, and E. T. Elliott. 2001. Grassland management and conversion into grassland: effects on soil carbon. Ecological Applications 11:343-355

Dahlgren, R. A., M. J. Singer, and X. Huang. 1997. Oak tree and grazing impacts on soil properties and nutrients in a California oak woodland. Biogeochemistry 39:45-64.

Del Grasso, S. J., D. S. OJima, W. J. Parton, E. Stehfest, M. Heistemann, B. Deangelo, AND S. Rose. 2009. Global scale DAYCENT model analysis of greenhouse gas emissions and mitigation strategies for cropped soils. Global and Planetary Change 67:44-50.

Derner, J. D., And G. E. Schuman. 2007. Carbon sequestration and rangelands: a synthesis of land management and precipitation effects. Journal of Soil and Water Conservation 62:77-85. 
Eshel, G., P. Fine, And M. J. Singer. 2007. Total soil carbon and water quality: an implication for carbon sequestration. Soil Science Society of America Journal 71:397-405.

Eviner, V. T., AND C. V. Hawkes. 2008. Embracing variability in the application of plant-soil interactions to the restoration of communities and ecosystems. Restoration Ecology 16:713-729.

Fierer, N., 0. A. Chadwick, and S. E. Trumbore. 2005. Production of $\mathrm{CO}_{2}$ in soil profiles of a California annual grassland. Ecosystems 8:412-429.

Follett, R. F., J. M. KImBLE, AND R. LAL. 2001. The potential of U.S. grazing lands to sequester carbon and mitigate the greenhouse effect. Boca Raton, FL, USA: Lewis Publishers. $410 \mathrm{p}$.

Frank, D. A., and S. J. McNaughton. 1993. Evidence for the promotion of aboveground grassland production by native large herbivores in Yellowstone National Park. Oecologia 96:157-161.

Gaman, T., And J. Firman. 2006. Oaks 2040: The status and future of oaks in California. Oakland, CA, USA: California Oak Foundation. 55 p.

George, M., J. Bartolome, N. McDougald, M. Connor, C. Vaughn, and G. Markegard. 2001. Annual range forage production. Oakland, CA, USA: Division of Agriculture and Natural Resources, University of California. ANR Publ. 8018. 9 p.

George, M., J. Clawson, J. Menke, and J. Bartolome. 1985. Annual grassland forage productivity. Rangelands 7:17-19.

Gessler, P. E., 0. A. Chadwick, F. Chamran, L. Althouse, and K. Holmes. 2000. Modeling soil-landscape and ecosystem properties using terrain attributes. Soil Science Society of America Journal 64:2046-2056.

Giusti, G. A., R. B. Standiford, D. D. McCreary, A. Merenlender, and T. Scott. 2004. Oak woodland conservation in California's changing landscape. Berkeley, CA, USA: University of California. White paper, IHRMP publication. $6 \mathrm{p}$.

Gordon, D. R., And K. J. Rice. 1992. Partitioning of space and water between two California annual grassland species. American Journal of Botany 79:967-976.

GrifFIN, J. 1977. Oak woodland. In: M. J. Barbour and J. Major (EDS.). Terrestrial vegetation of California. New York, NY, USA: John Wiley and Sons. p. 383-415.

Guo, Y. Y., R. Amundson, P. Gong, AND Q. Yu. 2006. Quantity and spatial variability of soil carbon in the conterminous United States. Soil Science Society of America Journal 70:590-600.

Havstad, K. M., D. C. Peters, B. Allen-Diaz, J. Bartolome, B. T. Bestelmeyer, D. Briske, J. Brown, M. Brunson, J. E. Herrick, L. Huntsinger, P. Johnson, L. Joyce, R. Pieper, A. J. SvejcAR, AND J. YAO. 2009. The western United States rangelands, a major resource. In: W. F. Wedin and S. L. Fales (EDS.). Grassland quietness and strength for a new American agriculture. Madison, WI, USA: American Society of Agronomy, Crop Science Society of America, and Soil Science Society of America. p. 75-93.

Heady, H., J. Bartolome, M. Pitt, G. Savelle, and M. Stroud. 1991. California prairie. In: R. T. Coupland (ED.). Natural grasslands. Ecosystems of the world. Volume 8A. Amsterdam, the Netherlands: Elsevier Scientific. p. 313-335.

Heady, H. F. 1956. Changes in a California annual plant community induced by manipulation of natural mulch. Ecology 37:798-812.

Heady, H. F. 1965. The influence of mulch on herbage production in an annual grassland. Proceedings of the 9th International Grassland Congress 1:391-394.

HedRICK, D. W. 1948. The mulch layer of California annual ranges. Journal of Rangeland Management 1:22-25.

Herman, D. J., L. J. Halverson, and M. K. Firestone. 2003. Nitrogen dynamics in an annual grassland: oak canopy, climate, and microbial population effects. Ecological Applications 13:593-604.

Hobbs, R. J., S. Arico, J. Aronson, J. S. Baron, P. Bridgewater, V. A. Cramer, P. R. Epstein, J. J. Ewel, C. A. Klink, A. E. Lugo, D. Norton, D. OJima, D. M. Richardson, E. W. Sanderson, F. Valladares, M. Vila, R. Zamora, and M. Zobel. 2006. Novel ecosystems: theoretical and management aspects of the new ecological world order. Global Ecology and Biogeography 15:1-7.

HobBS, R. J., AND H. A. Mooney. 1986. Community changes following shrub invasion of grassland. Oecologia 70:508-513.

Holland, E. A., W. J. Parton, J. K. Detling, and D. L. Coppock. 1992. Physiological responses of plant populations to herbivory and their consequences for ecosystem nutrient flow. American Naturalist 140:685-706.
Holland, V. L., and D. J. Kiel. 1995. California vegetation. Dubuque, IA, USA: Kendall/Hunt Publishing Company. 516 p.

Huntsinger, L., J. W. Bartolome, AND C. M. D’Antonio. 2007. Grazing management of California grasslands. In: J. Corbin, M. Stromberg, and C. M. D’Antonio (EDS.). Berkeley, CA, USA: University of California Press. p. 233-297.

[IPCC] Intergovernmental Panel on Climate Change. 2007. Climate change 2007: synthesis report. Contribution of Working Groups I, II and III to the Fourth Assessment Report of the Intergovernmental Panel on Climate Change. Core Writing Team, R. K. Pachauri and A. Reisinger [EDS.]. Geneva, Switzerland: IPCC. $104 \mathrm{p}$.

Jackson, L. E., R. B. Strauss, M. K. Firestone, and J. W. Bartolome. 1988. Plant and soil nitrogen dynamics in California annual grassland. Plant and Soil 110:9-17.

Jackson, R. B., J. Canadell, J. R. Ehleringer, H. A. Mooney, O. E. Sala, and E. D. Schulze. 1996. A global analysis of root distributions for terrestrial biomes. Oecologia 108:389-411.

Jackson, R. B., E. G. Jobbagy, R. Avissar, S. B. Roy, D. J. Barrett, C. W. Cook, K. A. Farley, D. C. le Maitre, B. A. McCarl, and B. C. Murray. 2005. Trading water for carbon with biological sequestration. Science 310:1944-1947.

Jackson, R. B., H. J. Schenk, E. G. Jobbagy, J. Canadell, G. D. Colello, R. E. Dickinson, C. B. Field, P. Friedlingstein, M. Heimann, K. Hibbard, D. W. Kicklighter, A. Kleidon, R. P. Neilson, W. J. Parton, O. E. Sala, and M. T. Sykes. 2000. Belowground consequences of vegetation change and their treatment in models. Ecological Applications 10:470-483.

JaCKson, R. D., AND J. W. BARtolome. 2002. A state-transition approach to understanding nonequilibrium plant community dynamics in Californian grasslands. Plant Ecology 162:49-65.

Jackson, R. D., AND J. W. Bartolome. 2007. Grazing ecology of California grasslands. In: J. Corbin, M. Stromberg, and C. M. D’Antonio (EDS.). Ecology and management of California grasslands. Berkeley, CA, USA: University of California Press. p. 197-206.

Jobbagy, E. G., and R. B. Jackson. 2000. The vertical distribution of soil organic carbon and its relation to climate and vegetation. Ecological Applications 10:423-436.

Jobbagy, E. G., And R. B. Jackson. 2004. The uplift of soil nutrients by plants: biogeochemical consequences across scales. Ecology 85:2380-2389.

Johnson, L. C., And J. R. Matchett. 2001. Fire and grazing regulate belowground processes in tallgrass prairie. Ecology 82:3377-3389.

KIEFT, T. L. 1994. Grazing and plant-canopy effects on semiarid soil microbial biomass and respiration. Biology and Fertility of Soils 18:155-162.

Kochy, M., AND S. D. WILSON. 2001. Nitrogen deposition and forest expansion in the northern Great Plains. Journal of Ecology 89:807-817.

Kroodsma, D. A., and C. B. Field. 2006. Carbon sequestration in Califronia agriculture, 1980-2000. Ecological Applications 16:1975-1985.

LAL, R. 2004. Agricultural activities and the global carbon cycle. Nutrient Cycling in Agroecosystems 70:103-116.

Lal, R., J. Kimble, E. Levine, and B. A. Stewart (eds.). 1995. Soil management and greenhouse effect. Boca Raton, FL, USA: Lewis Publishers. 385 p.

Lehmann, J. 2007. Bio-energy in the black. Frontiers in Ecology and the Environment 5:381-387.

Loeser, M. R., T. E. Crews, and T. D. Sisk. 2004. Defoliation increased aboveground productivity in a semi-arid grassland. Journal of Range Management 57:442-447.

Ma, F. S., S. Z. Kang, F. S. Li, J. H. Zhang, T. S. Du, X. T. Hu, and M. X. Wang. 2007 a. Effect of water deficit in different growth stages on stem sap flux of greenhouse grown pear-jujube tree. Agricultural Water Management 90:190-196.

Masiello, C. A., O. A. Chadwick, J. Southon, M. S. Torn, and J. W. Harden. 2004. Weathering controls on mechanisms of carbon storage in grassland soils. Global Biogeochemical Cycles. 18:GB4023, doi: 10.1029/2004GB002219.

Mariani, L., J. J. Jimenez, J. N. Asakawa, R. J. Thomas, and T. Decaens. 2007. What happens to earthworm casts in the soil? A field study of carbon and nitrogen dynamics in neotropical savannahs. Soil Biology and Biochemistry 39:757-767. 
McBride, J., and H. F. Heady. 1968. Invasion of grassland by Baccharis pilularis. Journal of Range Management 21:106-108.

McCulley, R. L., E. G. Jobbagy, W. T. Pockman, and R. B. Jackson. 2004. Nutrient uptake as a contributing explanation for deep rooting in arid and semi-arid ecosystems. Oecologia 141:620-628.

McNaughton, S. J. 1985. Ecology of a grazing ecosystem-the Serengeti. Ecological Monographs 55:259-294.

Miller, R. M., AND J. D. Jastrow. 1990. Hierarchy of root and mycorrhizal fungal interactions with soil aggregation. Soil Biology \& Biochemistry 22:579-584.

Parton, W. J., D. S. OJima, and D. S. Schimel. 1994. Environmental change in grasslands-assessment using models. Climatic Change 28:111-141.

Paustian, K., E. Levine, W. M. Post, and I. M. Rrzhova. 1997. The use of models to integrate information and understanding of soil $\mathrm{C}$ at the regional scale. Geoderma 79:227-260.

Polley, H. W., H. B. Johnson, and C. R. Tischler. 2003. Woody invasion of grasslands: evidence that $\mathrm{CO} 2$ enrichment indirectly promotes establishment of Prosopis glandulosa. Plant Ecology 164:85-94.

Post, W. M., AND K. C. Kwon. 2000. Soil carbon sequestration and land-use change: processes and potential. Global Change Biology 6:317-327.

Potter, K. N., And J. D. Derner. 2006. Soil carbon pools in central Texas: prairies, restored grasslands, and croplands. Journal of Soil and Water Conservation 61:124-128.

Puget, P., and L. E. Drinkwater. 2001. Short-term dynamics of root- and shootderived carbon from a leguminous green manure. Soil Science Society of America Journal 65:771-779.

Sanderman, J., and R. Amundson. 2008. A comparative study of dissolved organic carbon transport and stabilization in California forest and grassland soils. Biogeochemistry 89:309-327.

Sanderman, J., J. A. Baldock, and R. Amundson. 2008. Dissolved organic carbon chemistry and dynamics in contrasting forest and grassland soils. Biogeochemistry 89:181-198.

Savelle, G. D. 1977. Comparative structure and function in a California annual and native bunchgrass community [dissertation]. Berkeley, CA, USA: University of California.

Schimel, D. S., B. H. Braswell, E. A. Holland, R. McKeown, D. S. Ojima, T. H. Painter, W. J. Parton, and A. R. Townsend. 1994. Climatic, edaphic, and biotic controls over storage and turnover of carbon in soils. Global Biogeochemical Cycles 8:279-293.

Schlesinger, W. H., J. F. Reynolds, G. L. Cunningham, L. F. Huenneke, W. M. Jarrell, R. A. Virginia, AND W. G. Whitford. 1990. Biological feedbacks in global desertification. Science 247:1043-1048.

Schroter, D., W. Cramer, R. Leemans, I. C. Prentice, M. B. Araújo, N. W. Arnell, A. Bondeau, H. Bugmann, T. R. Carter, C. A. Graciah, A. de la Vega-Leinert, M. Erhard, F. Ewert, M. Glendining, J. I. House, S. Kankaanpaa, R. J. T. Klein, S. Lavorel, M. Lindner, M. J. Metzger, J. Meyer, T. D. Mitchell, I. Reginster, M. Rounsevell, S. Sabate, S. Sitch, B. Smith, J. Smith, P. Smith, M. T. Sykes, K. Thonicke, W. Thuiller, G. Tuck, S. Zaehle, and B. Zierl. 2005. Ecosystem service supply and vulnerability to global change in Europe. Science 310:1333-1337.
Schuman, G. E., H. H. Janzen, and J. E. Herrick. 2002. Soil carbon dynamics and potential carbon sequestration by rangelands. Environmental Pollution 116:391-396.

Shuster, W. D., S. Subler, and E. L. McCoy. 2001. Deep-burrowing earthworm additions changed the distribution of soil organic carbon in a chisel-tilled soil. Soil Biology and Biochemistry 33:983-996.

Silver, W. L., A. E. Lugo, and D. Farmer. 2002. Soil organic carbon in tropical forests of the U. S. In: J. Kimble, R. Birdsey, L. Heath, R. Follett, and R. Ratan (EDS.). The potential of U.S. forest soils to sequester carbon and mitigate the greenhouse effect. Boca Raton, FL, USA: Lewis Publishers. p. 363-382.

Silver, W. L., A. E. Lugo, And M. Keller. 1999. Soil oxygen availability and biogeochemistry along rainfall and topographic gradients in upland wet tropical forest soils. Biogeochemistry 44:301-328.

Silver, W. L., R. Ostertag, and A. E. Lugo. 2000. The potential for carbon sequestration through reforestation of abandoned tropical agricultural and pasture lands. Restoration Ecology 8:394-407.

Six, J. A., E. T. Elliott, and K. Paustian. 2000. Soil macro aggregate turnover and micro aggregate formation: a mechanism for $\mathrm{C}$ sequestration under no-tillage agriculture. Soil Biology and Biochemistry 32:2099-2103.

Smiтt, P. 2004. Soils as carbon sinks: the global context. Soil Use and Management 20:212-218

Smith, P., C. M. Fang, J. J. C. Dawson, and J. B. Moncrieff. 2008. Impact of global warming on soil organic carbon. Advances in Agronomy 97:1-43.

Soussana, J. F., P. Loiseau, N. Vuichard, E. Ceschia, J. Balesdent, T. Chevallier, and D. Arrouars. 2004. Carbon cycling and sequestration opportunities in temperate grasslands. Soil Use and Management 20:219-230.

Steenwerth, K. L., L. E. Jackson, F. J. Calderon, M. R. Stromberg, and K. M. Scow. 2002. Soil microbial community composition and land use history in cultivated and grassland ecosystems of coastal California. Soil Biology and Biogeochemistry 34:1599-1611.

Stromberg, M. R., P. Kephart, and V. Yadon. 2001. Composition, invasibility, and diversity in coastal California grasslands. Madrono 48:236-252.

Trumbore, S. E., O. A. Chadwick, and R. Amundson. 1996. Rapid exchange between soil carbon and atmospheric carbon dioxide driven by temperature change. Science 272:393-396.

Turner, C. L., T. R. Seastedt, and M. I. Dyer. 1993. Maximization of aboveground grassland production - the role of defoliation frequency, intensity, and history. Ecological Applications 3:175-186.

Van AuKen, 0. W. 2000. Shrub invasions of North American semiarid grasslands. Annual Review of Ecology and Systematics 31:197-215.

Waldrop, M. P., and M. K. Firestone. 2006. Seasonal dynamics of microbial community composition and function in oak canopy and open grassland soils. Microbial Ecology 52:470-479.

Zavaleta, E. S., and L. S. Kettley. 2006. Ecosystem change along a woody invasion chronosequence in a California grassland. Journal of Arid Environments 66:290-306 